\title{
Perencanaan manajemen risiko atlet berprestasi Indonesia (Studi kasus atlet dengan risiko cedera tinggi)
}

\author{
Ahmad Briezy Baihaqi ${ }^{1}$ *, Maria Puspitasari ${ }^{1}$, Maria Zuraida ${ }^{1}$, Ahmad Nurcholis ${ }^{2}$ \\ ${ }^{1}$ Program Studi Kajian Ketahanan Nasional, Sekolah Kajian Stratejik dan Global, Universitas \\ Indonesia. Jalan Salemba Raya No.4, Senen, Jakarta Pusat 10430, Indonesia. \\ ${ }^{2}$ Politik Internasional, Sekolah Ilmu Politik dan Administrasi Publik, Universitas Shandong, \\ 72 Binghai Road, Jimo, Qingdao, P. R. Tiongkok 266237 \\ * Coressponding Author. E-mail: brezy.baihaqy@gmail.com
}

Received: August 11, 2020; Revised: August 15, 2020; Accepted: April 30, 2021

\begin{abstract}
Abstrak: Atlet berprestasi memiliki risiko yang bisa menyebabkan kesulitan keuangan saat pensiun dari olahraga. Atlet dengan risiko cedera tinggi berpeluang lebih besar mengalami kesulitan keuangan karena berpotensi pensiun lebih dini akibat cedera. Tujuan dari penelitian ini adalah untuk mengetahui bagaimana manajemen risiko yang dilakukan atlet berprestasi dari cabang olahraga dengan risiko cedera tinggi untuk meminimalisir risiko saat pensiun dengan mengoptimalkan pendapatan yang dimiliki ketika masih aktif sebagai atlet. Landasan konsep yang digunakan dalam penelitian adalah manajemen risiko dengan dua perencanaan, yaitu perencanaan keuangan menggunakan perencanaan keuangan pribadi milik Kapoor, Dlabay dan Hughes (2009) dan perencanaan pendidikan. Wawancara mendalam dilakukan terhadap empat atlet berprestasi dan satu perwakilan federasi serta studi dokumen. Hasilnya, manajemen risiko yang dimiliki keempat informan yaitu tabungan dari gaji pegawai negeri sipil dan honor atlet, investasi berupa tanah dan properti, dan rumah atas nama sendiri. Manajemen risiko yang dimiliki masih membuat informan rentan terpapar risiko saat pensiun karena hanya mengelola risiko dari sisi materi yang bisa habis. Sementara itu, keempat informan tidak melanjutkan pendidikan tinggi. Idealnya, manajemen risiko juga dilakukan oleh federasi dengan membuka peluang beasiswa untuk atlet melanjutkan pendidikan tinggi. Rekomendasi dari penelitian ini yaitu pemerintah perlu mendorong dan menyediakan beasiswa afirmasi untuk pendidikan tinggi atlet.
\end{abstract}

Kata kunci : ketahanan ekonomi, atlet, manajemen risiko, olahraga

\section{Indonesian athlete risk management planning (Case study athletes with high risk injury)}

Abstract: High-achieving athletes are at risk of causing financial difficulties when they retire from sports. Athletes with high injuries are more likely to experience financial difficulties due to early retirement due to injury. The purpose of this study was to see how risk management performed by high-achieving athletes from sports with high injuries to minimize risks at retirement by optimizing the income they had while still active as an athlete. The concept used in this research is risk management with two plans, financial planning using private financial planning by Kapoor, Dlabay and Hughes (2009) and educational planning. In-depth interviews were conducted with four athletes and one representative of the federation as well as document studies. The results of risk management owned by the four informants are savings from salaries of civil servants and athletes' honor, investment in the form of land and property, and houses in their own names. Athlete is still vulnerable to be exposed by risk during retirement. The four informants did not continue their higher education. Risk management is also carried out by the federation with scholarship opportunities for athletes to continue their higher education. The recommendation of this research is that the government encourages and provides affirmative scholarships for higher education athletes.

Keywords: economic resilience, athlete, risk management, sport

How to Cite: Baihaqi, A., B., Puspitasari, M., Zuraida, M., \& Nurcholis, A. (2021). Perencanaan manajemen risiko atlet berprestasi Indonesia (Studi kasus atlet dengan risiko cedera tinggi). Jurnal Keolahragaan, 9(1), 137-147. DOI: https://doi.org/10.21831/jk.v9i1.33856 
Jurnal Keolahragaan 9 (1), 2021 - 138

Ahmad Briezy Baihaqi, Maria Puspitasari, Maria Zuraida, Ahmad Nurcholis

\section{PENDAHULUAN}

Ketentuan soal atlet berprestasi diatur dalam Peraturan Presiden Republik Indonesia No. 95 tahun 2017 tentang Peningkatan Prestasi Olahraga Nasional. Di dalam peraturan presiden tersebut, atlet berprestasi dipilih oleh induk organisasi cabang olahraga untuk mengikuti pemusatan latihan nasional untuk kemudian ditetapkan oleh cabang olahraga yang bersangkutan. Atlet berprestasi berada di pemusatan latihan untuk jangka waktu yang lama sebagai persiapan mengikuti kejuaraan-kejuaraan internasional seperti SEA Games-Asean Para Games, Asian Games-Asian Para Games dan OlimpiadeParalimpiade.

Atlet berprestasi yang masuk ke dalam pemusatan latihan nasional memperoleh fasilitas penuh, ditanggung seluruhnya, mulai dari sandang, pangan, papan dan honor bulanan (Kemenpora, 2018a). Honor per bulan yang didapat atlet berprestasi juga akan ditambah bonus uang tunai dari negara jika sang atlet berhasil meraih medali di kompetisi internasional. Bonus akan semakin besar mengikuti tingkat kompetisi yang diikuti atlet, terlebih jika Indonesia menjadi tuan rumah. Seperti saat Indonesia menjadi tuan rumah Asian Games ke-18, tahun 2018, di kota Jakarta-Palembang, dan Asian Para Games ke-3 tahun 2018, di Jakarta (Kemenpora, 2018b). Selain bonus uang tunai, Pemerintah Indonesia juga mengangkat atlet berprestasi yang meraih medali di Asian Games 2018 dan Asian Para Games 2018 sebagai Calon Pegawai Negeri Sipil (CPNS) (Setkab.go.id, 2018).

Pemerintah Indonesia di bawah kepemimpinan presiden Joko Widodo sangat memperhatikan perkembangan olahraga dan mengapresiasi atlet-atlet yang berprestasi. Fakta itu diantaranya terlihat dalam Instuksi Presiden Nomor 3 Tahun 2019 tentang Percepatan Pembangunan Persepakbolaan Nasional, Peraturan Presiden Nomor 95 Tahun 2017 tentang Peningkatan Prestasi Olahraga Nasional yang ia terbitkan, maupun dengan mengapresiasi atlet-atlet berprestasi peraih medali OlimpiadeParalimpiade, Asian Games-Asian Para Games dan SEA Games-Asean Para Games. Sayangnya, meski memiliki pendapatan dan bonus uang tunai yang besar, atlet tetap dihantui risiko yang krusial, seperti karir yang singkat dan cedera. Beberapa atlet Indonesia yang memiliki karir singkat diantaranya adalah karateka Indonesia, Jintar Simanjuntak. Dirinya memutuskan pensiun di usia 31 tahun. Di samping itu, ada juga Sprinter peraih medali SEA Games dan Asian Games, Fadlin, yang pensiun di usia 30 tahun, dan legenda bulutangkis Liliyana Natsir, pensiun di usia 34 tahun. Belum lagi jika atlet memiliki cedera yang susah sembuh dan mengharuskan pensiun dini, seperti ratu wushu Asia asal Indonesia, Lindswell Kwok, yang memutuskan pensiun di usia 27 tahun karena cedera lutut.

Menurut Vaughn dalam Spikin (2013), dirinya membagi risiko menjadi dua bagian, yaitu risiko keuangan dan risiko non-keuangan. Risiko keuangan meliputi tiga hal, yaitu individu yang terkena kerugian, aset atau pendapatan yang bisa hilang atau habis sehingga menyebabkan kerugian keuangan, dan terakhir, bahaya seperti cedera yang bisa menyebabkan kerugian. Risiko tersebut jika tidak dihadapi dengan manajemen yang baik, akan menjadikan atlet rentan terhadap masalah keuangan seperti terjerat hutang, bangkrut, hingga jatuh miskin. Di Indonesia, cerita-cerita atlet berprestasi Indonesia yang hidup susah di masa tua menjadi ironi saat seharusnya atlet mampu mempergunakan pendapatan yang dimiliki untuk hal-hal yang bersifat produktif. Misalnya mantan atlet dayung peraih medali SEA Games 1997, Karni, yang menjadi tukang sapu (Kurnia, 2019), atlet angkat besi era 90-an, Denny, yang meraih berbagai prestasi Internasional juga akhirnya membuka bengkel kecil di Makassar, dan atlet perahu naga, Leni Haini, yang meraih berbagai kejuaraan internasional tahun 1997 hingga 1998 kesulitan mendapatkan pekerjaan hingga harus bekerja menjadi buruh cuci (Syam, 2016). Selain itu, tentunya atlet-atlet profesional penyandang cacat akan lebih rentan dalam menghadapi ketidakpastian di masa pensiun. Maka itu, dengan risiko yang dihadapi atlet, atlet dituntut memiliki manajemen yang baik untuk meminimalisir risiko saat pensiun. Manajemen risiko tersebut bisa berupa perencanaan keuangan dan perencanaan pendidikan untuk meminimalisir risiko keuangan dan non-keuangan.

Perencanaan keuangan bisa berupa menempatkan pendapatan pada investasi saham, obligasi atau pasar uang (Fox et al., 2012: 274), menabung dengan perencanaan jangka panjang (Lomboy et al., 2019:342), memiliki penasihat keuangan pribadi (Danowski, 2012: 2), membeli properti dan atau membangun usaha untuk memastikan pendapatan yang dimiliki tidak habis untuk hal-hal yang tidak produktif. Sebagai amsal, memiliki karir profesional di luar karir sebagai atlet menjadi tuntutan para atlet Prancis untuk merencanakan masa depan setelah berhenti dari olahraga (Stambulova, Stephan, \& Jäphag, 2007: 104). 
Kondisi keuangan atlet di masa pensiun memang menjadi permasalahan umum di berbagai negara. Rata-rata atlet football yang bermain di Liga Football Nasional Amerika Serikat menyatakan bangkrut setelah dua tahun memasuki masa pensiun (Carlson, Kim, Lusardi, \& Camerer, 2015: 9). Berdasarkan penelitian Balliauw \& Van Den Spiegel (2018), meneliti menggunakan pendekatan kuantitatif dan kualitatif, menemukan faktor-faktor penyebab permasalahan keuangan atlet. Hasilnya, ditemukan beberapa faktor yang berdampak pada masalah keuangan. Seperti, atlet yang memiliki kepribadian ekstrovert, (lebih cenderung) untuk berinvestasi di real estate, dan jumlah tanggungan (anak) juga merupakan faktor yang berdampak pada masalah keuangan. Satu hal yang perlu digarisbawahi adalah bahwa penelitian ini tidak memasukkan rasio tabungan sebagai manajemen risiko karena tidak adanya data mengenai informasi tabungan atlet.

Di samping itu, atlet-atlet berprestasi yang tergabung dalam pemusatan latihan nasional juga ada yang berasal dari cabang olahraga dengan risiko cedera tinggi, seperti atlet angkat besi, atlet angkat berat dan atlet tinju. Menurut Bledsoe, Li dan Levy (2005) rata-rata cedera dalam pertandingan tinju profesional tinggi, yaitu 17,1 per 100 pertandingan, dengan atlet tinju pria lebih berisiko cedera. Dengan kalah KO berisiko cacat jangka panjang akibat cedera neurologis. Sementara berdasarkan catatan Aasa, Svartholm Andersson dan Berglund (2017), rata-rata 20\% dari semua cedera yang didapat adalah cedera otot dan 25\% cedera tendon lebih dominan pada atlet angkat besi. Pada Olimpiade 2008, 5 atlet mengalami patah ligamen atau tendon. Jika cedera, atlet paling lama merasakan gejala lebih dari 4 minggu dan bisa beristirahat hingga 2 tahun.

Menurut Keogh dalam penelitian Aasa, Svartholm Andersson dan Berglund (2017), melaporkan, cedera yang dialami atlet angkat berat sebesar $60 \%$ berakhir akut dan $40 \%$ kronis, dengan $20 \%$ diklasifikasikan sebagai cedera parah dengan waktu istirahat lebih dari seminggu. Raske dan Norlin juga melaporkan bahwa cedera yang umum dialami atlet angkat berat yaitu 93\% cedera bahu, $85 \%$ cedera pada punggung bagian bawah, dan $80 \%$ cedera lutut yang mengakibatkan gejala yang berlangsung selama lebih dari 4 minggu. Cedera tersebut memaksa atlet untuk beristirahat dari pelatihan dan kompetisi untuk waktu rata-rata 11,5 hari.

Pandemi Covid-19 yang sedang melanda dunia tidak terkecuali Indonesia juga memberikan dampak bagi atlet dari sisi ekonomi. Menurut Instagram Prestasi Olahraga, beberapa pemusatan latihan nasional dihentikan sementara dan atlet dipulangkan ke daerah masing-masing untuk menjalani latihan mandiri. Penghentian pemusatan latihan nasional membuat atlet berisiko kehilangan honor. Sehingga diperlukan manajemen yang baik untuk meminimalisir risiko di masa pandemi Covid-19 agar atlet tetap bisa memenuhi kebutuhan sehari-hari. Peneliti melakukan wawancara terhadap atlet dari ketiga cabang olahraga yaitu angkat besi, angkat berat dan tinju untuk mengetahui manajemen risiko apa yang dilakukan atlet serta dampak pandemi terhadap atlet dan bagaimana manajemen risiko yang dimiliki bisa meningkatkan ketahanan ekonomi atlet di masa pensiun. Wawancara juga dilakukan terhadap perwakilan federasi untuk mengetahui manajemen risiko yang dimiliki oleh federasi untuk menyiapkan atlet memasuki masa pensiun.

\section{METODE}

Pendekatan yang digunakan dalam penelitian ini yaitu deskriptif kualitatif dengan metode wawancara mendalam dan studi dokumen. Penelitian ini dilakukan di tengah kondisi pandemi Covid19 sehingga tidak memungkinkan untuk melakukan wawancara tatap muka. Perbedaan geografis dengan informan juga menjadikan penelitian ini menggunakan metode wawancara mendalam melalui bantuan teknologi seperti aplikasi Zoom Cloud Meeting dan WhatsApp. Wawancara dilakukan 1-30 Juni 2020.

Subjek penelitian ini adalah perwakilan federasi dan atlet berprestasi Indonesia yang meraih medali di Olimpiade, Paralimpiade, Asian Games, Asian Para Games, SEA Games atau Asean Para Games dan menjadi pegawai negeri sipil di lingkungan Kementerian Pemuda dan Olahraga atau pemerintah daerah. Tiga informan yaitu atlet angkat berat $\mathrm{N}$, atlet tinju A dan $\mathrm{S}$ merupakan pegawai negeri sipil di Kementerian Pemuda dan Olahraga, dan satu informan yaitu atlet angkat besi $\mathrm{T}$ merupakan pegawai negeri sipil di Dinas Pemuda dan Olahraga Pemerintah Provinsi. Informan perwakilan federasi dari federasi angkat besi (PB PABBSI). Teknik analisis data yang digunakan yaitu analisis deskriptif dengan menganalisis hasil wawancara mengenai manajemen risiko perencanaan keuangan menggunakan konsep perencanaan keuangan pribadi milik Kapoor, Dlabay, \& Hughes (2009). Delapan komponen perencanaan keuangan pribadi yaitu sumber pendapatan, perencanaan keuangan, tabungan, pinjaman, pengeluaran, mengelola risiko, investasi dan perencanaan pensiun. 


\section{HASIL DAN PEMBAHASAN}

\section{Risiko yang Dihadapi Atlet}

Berdasarkan hasil wawancara atlet yang menjadi informan dalam penelitian ini, keempat informan mulai meniti karier di usia 13-15 tahun seperti T yang memulai latihan angkat besi di usia 13 tahun, $\mathrm{N}$ mulai menekuni angkat berat saat usia 14 tahun, S dan A memilih karier atlet tinju di usia 15 tahun. Memulai karier di usia muda, informan menyadari risiko yang dihadapi sebagai atlet dari cabang olahraga fisik. Beberapa risiko yang disadari seperti diungkapkan $T$ yaitu cedera yang pasti akan dialami atlet angkat besi serta intensitas latihan yang menurun karena faktor usia. Dampak dari turunnya intensitas latihan yaitu menurunnya prestasi sedikit demi sedikit. $\mathrm{N}$ juga mengungkapkan bahwa cedera bagi atlet angkat berat sudah hal yang biasa dan sering terjadi. Apalagi jika program latihan di pelatnas berat. Menurut $\mathrm{N}$ jika dalam dua minggu latihan tidak mengalami sakit itu sudah bersyukur.

Dari beberapa penuturan atlet di atas didapat bahwa risiko yang disadari oleh para informan adalah risiko cedera, hilangnya waktu akibat fokus latihan, jauh dari keluarga karena jarak dari rumah ke pelatnas jauh dan mental saat menerima hujatan. Selain risiko tersebut, di masa pandemi Covid-19 seperti saat ini yang melumpuhkan aktivitas perekonomian hampir di seluruh wilayah Indonesia, terutama wilayah yang mengandalkan pariwisata, juga berdampak pada ekonomi atlet baik langsung maupun tidak langsung. Atlet tinju S mengatakan pandemi Covid-19 yang membatasi pergerakan fisik orang membuat pelatda tertunda sehingga belum menerima honor. Selain itu, pandemi Covid-19 juga membuat pertandingan ditiadakan. Menurut petinju Indonesia Chris John, pertandingan bagi atlet tinju selain menjadi sumber pendapatan juga meningkatkan jam terbang (Sholih, 2016). Menurut website BoxRec yang berisi data-data atlet tinju dan pertandingan tinju menunjukkan dalam satu tahun, atlet $S$ bisa mengikuti 4 pertandingan pada tahun 2018 dan atlet A ikut dalam 5 pertandingan amatir tinju pada tahun 2019.

Atlet $\mathrm{N}$ juga sangat merasakan dampak dari pandemi yang melumpuhkan perekonomian daerah tempat tinggalnya. Provinsi asal atlet $\mathrm{N}$ merupakan salah satu daerah yang mengandalkan pariwisata sebagai pemasukan daerah. Berkurangnya wisatawan membuat banyak tempat usaha merumahkan pegawainya termasuk keluarga $\mathrm{N}$ yang mendapatkan pemasukan dari wisatawan yang datang. Selain harus menanggung kebutuhan keluarga, $\mathrm{N}$ juga tidak mendapatkan honor selama pandemi. Berbeda dengan ketiga informan yang terdampak pandemi Covid-19, T mengatakan walaupun latihan di rumah tidak ada kendala honor selama pandemi karena pelatnas angkat besi masih berlanjut. Berbeda dengan atlet dari pelatnas cabang olahraga lain yang dipulangkan. Pemulangan atlet ke daerah masing-masing merupakan salah satu bentuk pencegahan yang dilakukan federasi untuk kesehatan atlet. Walaupun berada di rumah masing-masing, atlet masih menjalani latihan yang disesuaikan dengan pengawasan dari pelatih. Hal tersebut sesuai dengan penelitian yang dilakukan Toresdahl \& Asif (2020) yang menyatakan bahwa salah satu manajemen untuk atlet di masa pandemi Covid-19 adalah dengan memulangkan atlet ke daerah.

Di Indonesia, belum ada penelitian mengenai dampak pandemi terhadap ekonomi atlet. Namun secara nasional pandemi Covid-19 berdampak pada pertumbuhan perekonomian Indonesia. Efek globalisasi juga membuat Indonesia terdampak dari pelambatan ekonomi beberapa negara besar seperti Tiongkok, Eropa, Jepang dan Amerika Serikat (Nasution, Erlina \& Muda, 2020).

\section{Manajemen Risiko}

Atlet berprestasi yang pensiun dari olahraga dan kemudian hidup susah dan mengalami kesulitan keuangan merupakan efek dari serangkaian risiko yang tidak dihadapi dengan manajemen serta perencanaan yang baik. Berdasarkan hasil wawancara mendalam terhadap keempat informan dan satu wakil federasi diketahui bahwa terdapat dua unsur perencanaan yaitu perencanaan keuangan dan perencanaan pendidikan yang dilakukan oleh atlet dan federasi

\section{Perencanaan Keuangan Atlet}

Dari hasil wawancara didapatkan bahwa penghasilan saat ini berasal dari gaji pegawai negeri sipil dan honorarium atlet. Atlet angkat besi T mengungkapkan bahwa pendapatan yang dimiliki saat ini berasal dari gaji dan tunjangan PNS, honorarium tim nasional angkat besi Indonesia persiapan Olimpiade, dan honorarium dari provinsi sebagai uang desentralisasi latihan persiapan PON Papua. Dengan status sudah menikah, $\mathrm{T}$ juga mendapat dukungan penghasilan dari istri yang juga seorang 
pelatih dan mantan atlet angkat besi. Atlet angkat berat $\mathrm{N}$ mengungkapkan bahwa penghasilan yang dimiliki saat ini berasal dari gaji dan tunjangan pegawai negeri sipil di Kemenpora. Di masa pandemi, $\mathrm{N}$ tidak mendapatkan honorarium karena pemusatan latihan nasional dihentikan sementara. $\mathrm{N}$ juga mendapatkan penghasilan hasil kerjasama dengan perusahaan multi nasional yang dibayar dua sampai tiga kali dalam satu tahun. Atlet tinju A menyatakan penghasilan saat ini bersumber dari gaji dan tunjangan pegawai negeri sipil di Kemenpora. A tetap mendapatkan honorarium dari PP Pertina dan honorarium dari pemusatan latihan daerah meskipun latihan dilaksanakan secara mandiri di masa pandemi. Atlet tinju S mengungkapkan sumber penghasilan saat ini berasal dari gaji dan tunjangan pegawai negeri sipil dan honorarium pemusatan latihan daerah. Untuk honorarium atlet, $\mathrm{S}$ mengatakan di masa pandemi ini dirinya belum menerima honor karena pemusatan latihan daerah belum dimulai.

Keempat informan juga mendapatkan penghasilan tambahan saat berhasil meraih medali di kejuaraan-kejuaraan Internasional seperti SEA Games-Asean Para Games, Asian Games-Asian Para Games, dan Olimpiade-Paralimpiade. Penghasilan tambahan tersebut berupa bonus uang tunai yang nominalnya disesuaikan dengan medali yang diraih dan kejuaraan yang diikuti. Penghasilan yang dimiliki kemudian dialokasikan sesuai dengan kebutuhan, baik atas saran dari orang terdekat seperti istri dan keluarga ataupun atas kebijakan sendiri. Atlet $\mathrm{T}$ sebelum menikah mempercayakan penggunaan bonus uang tunai yang diraihnya kepada orang tua di kampung. Orang tua $\mathrm{T}$ mengalokasikan bonus uang tunai milik $\mathrm{T}$ untuk dibelikan sawah dan membangun kontrakan dengan sertifikat atas nama $\mathrm{T}$. Honorarium atlet digunakan $\mathrm{T}$ untuk memenuhi kebutuhan sehari-hari. Saat menikah, penggunaan bonus uang tunai dan penghasilan dari gaji pegawai negeri sipil dan honorarium atlet dipakai sendiri bersama istri untuk kebutuhan keluarga dan membayar cicilan. $\mathrm{T}$ juga memiliki tabungan dan menjadikan tabungan untuk menyimpan penghasilan sekaligus sebagai dana darurat yang bisa digunakan dalam kebutuhan mendesak seperti saat anak sakit dan biaya sekolah.

$\mathrm{N}$ mengatakan mengambil keputusan sendiri dalam penggunaan penghasilan baik gaji pegawai negeri sipil, honor atlet sampai bonus uang tunai. Penggunaan bonus uang tunai, $\mathrm{N}$ menggunakan alokasi 50-50. 50\% dari penghasilan digunakan untuk biaya hidup $\mathrm{N}$ dan keluarga, 50\% sisanya ditabung sebagai dana darurat agar bisa digunakan dalam kebutuhan mendesar. Sedangkan bonus uang tunai dialokasikan untuk investasi dengan membeli tanah di kampung halaman. Atlet tinju A mengalokasikan penghasilannya untuk kebutuhan sehari-hari, membantu ekonomi orang tua dan menabung dengan alasan sebagai simpanan untuk masa depan saat tidak lagi aktif sebagai atlet. A mengambil keputusan sendiri dalam hal merencanakan keuangan pribadinya. Atlet tinju S meminta pendapat keluarga sebelum merencanakan keuangannya. Selain digunakan untuk kebutuhan pribadi, S juga mengalokasikan penghasilannya untuk membeli peralatan latihan. Saat meraih bonus uang tunai di Asian Games 2018, S juga mengalokasikannya untuk membantu orang tua dan menabung sebagai dana darurat.

Dari hasil wawancara tersebut didapatkan bahwa sumber dana tabungan atlet berasal dari gaji pegawai negeri sipil dan honorarium atlet serta bonus kejuaraan yang diperoleh setelah digunakan untuk investasi atau membantu orang tua. Tabungan juga menjadi salah satu jaring pengaman masa depan atlet ketika pensiun dari olahraga. Selain itu tabungan dijadikan dana darurat yang bisa dipakai sewaktuwaktu untuk kebutuhan mendesak.

Selain menabung, informan juga ada yang memiliki pinjaman, menghindari pinjaman, serta tidak memiliki pinjaman. T memiliki pinjaman ke Bank Rakyat Indonesia (BRI). Pinjaman dari BRI dan bonus uang tunai yang didapat $\mathrm{T}$ dari Olimpiade digunakan untuk membeli tanah seluas 600 meter persegi dan membangun rumah di atas tanah tersebut seluas 100 meter persegi. Untuk membayar cicilan pinjaman BRI hingga tahun 2025, T mengatakan menggunakan tunjangan kinerja pegawai negeri sipil. Rumah saat ini ditempati oleh istri dan anaknya.

Selain memiliki cicilan di BRI hingga tahun 2025, T juga memiliki kredit kendaraan bermotor berupa mobil Mazda Biante tahun 2016 dengan jangka waktu cicilan selama 5 tahun hingga tahun 2021. Berdasarkan hasil penelusuran penulis melalui google dengan kata kunci tabel angsuran Mazda Biante pada rentang waktu 2015-2016, didapat brosur Mazda Samarinda yang berisi harga on the road Mazda Biante tahun 2016 di Samarinda sebesar Rp. 428.900.000 dengan angsuran yang harus dibayar jika mencicil selama 5 tahun yaitu sebesar Rp. 9.280.000.

Berbeda dengan $\mathrm{T}, \mathrm{N}$ peraih medali berbagai kejuaraan tidak berani memiliki pinjaman sepeser pun. $\mathrm{N}$ memiliki prinsip hidup apa adanya, sederhana dan semampunya. Jika ada keinginan untuk membeli sesuatu dan uang yang dimiliki tidak cukup, $\mathrm{N}$ lebih memilih menabung terlebih dahulu hingga uangnya cukup. Memiliki hutang dengan jumlah jutaan di masa pandemi seperti ini bisa sangat 
membebani. Dua informan lainnya, atlet tinju A dan S mengatakan tidak memiliki cicilan apapun baik berupa pinjaman di bank atau pinjaman kendaraan bermotor. Tidak disebutkan secara khusus alasan tidak memiliki cicilan. Selain pinjaman, informan juga memiliki pengeluaran rutin setiap bulannya. T memiliki tanggungan satu istri dan dua orang anak. Pengeluaran untuk kebutuhan sehari-hari yang dilakukan T setiap bulannya berkisar Rp. 2 juta sampai Rp. 3 juta. Selain untuk kebutuhan sehari-hari, T juga memiliki pengeluaran rutin untuk membayar cicilan KUR BRI dan cicilan mobil Mazda Biante. T mengatakan bahwa tunjangan kinerja digunakan untuk membayar cicilan mobil.

Atlet angkat berat $\mathrm{N}$ yang tinggal bersama orang tua dan saudara kandungnya mengungkapkan menggunakan pendapatannya untuk kebutuhan diri sendiri dan keluarga. $\mathrm{N}$ menggunakan $50 \%$ penghasilannya untuk kebutuhan sendiri dan keluarga serta 50\% pendapatan ditabung. Meskipun tidak mendapatkan honor selama pandemi tapi $\mathrm{N}$ mengungkapkan masih memiliki tabungan untuk kebutuhan sehari-hari. Atlet tinju S selain menggunakan pendapatan untuk membantu keluarga dan kebutuhan sehari-hari juga dipakai untuk membeli peralatan latihan. Pengeluaran rutin S setiap bulan sekitar Rp. 2 juta sampai Rp. 3 juta. Dari hasil wawancara tersebut diketahui dalam kasus $\mathrm{N}$ yang tidak mendapatkan honorarium pemusatan latihan nasional di masa pandemi, tabungan yang dimiliki berperan penting untuk bisa survive di masa pandemi. $\mathrm{N}$ mengatakan tidak bisa jika hanya mengandalkan gaji dan tunjangan pegawai negeri sipil di masa pandemi.

Informan dalam penelitian ini merupakan atlet dengan risiko cedera tinggi. Diperlukan pengelolaan risiko yang dimiliki atlet untuk melindungi pendapatan dan sumber daya yang dimiliki serta meminimalisir pengeluaran jika terkena risiko seperti cedera. Saat ini asuransi yang dimiliki $\mathrm{T}$ hanya BPJS bersama istrinya sedangkan anak-anak T tidak memiliki asuransi. T mengungkapkan sengaja tidak membuat BPJS untuk anaknya karena jika berobat menggunakan BPJS mekanismenya rumit dan tidak semua rumah sakit menerima BPJS. Jadi T menggunakan penghasilannya untuk biaya berobat jika kedua anaknya sakit. $\mathrm{N}$ mengatakan pernah mengalami cedera parah setelah turnamen pada tahun 2016 dan harus operasi serta harus menjalani pengobatan dalam waktu yang lama hingga 5 bulan setelah operasi. Saat itu N tidak memiliki asuransi termasuk BPJS. Biaya operasi ditanggung federasi namun biaya berobat ditanggung sendiri. Di masa terburuk itu, $\mathrm{N}$ tidak memiliki rencana apapun jika memang harus berhenti dari olahraga karena cedera. Atlet tinju A dan S mengatakan saat ini tidak memiliki asuransi termasuk BPJS.

Dari hasil wawancara dengan keempat atlet didapatkan bahwa ketiga atlet yaitu N, A dan S tidak memiliki asuransi apapun yang semestinya dimiliki atlet sebagai bagian dari pengelolaan risiko agar ketika terkena cedera dan harus menjalani operasi dan pengobatan tidak terlalu mengurasi tabungan yang dimiliki. Ketiga atlet baru memiliki asuransi ketika sudah menjadi pegawai negeri sipil. Tanpa pengelolaan risiko yang baik, atlet akan rentan kehabisan sumber daya dan penghasilan sehingga bisa berujung pada kesulitan finansial. Atlet tidak menyadari pentingnya asuransi seperti BPJS sebagai jaring pengaman saat atlet mengalami cedera.

Selain asuransi, diketahui juga investasi dimiliki informan. Investasi dilakukan dengan harapan dana yang diinvestasikan saat ini akan memiliki pertambahan di kemudian hari atau memberi nilai tambah ekonomi. T mengatakan bahwa sumber dana yang digunakan untuk melakukan investasi adalah hasil dari bonus uang tunai yang diraih sebelum menikah. Bonus uang tersebut diberikan kepada orang tua di kampung halaman untuk diinvestasikan berupa sawah dan membangun kontrakan dengan sertifikat atas nama $\mathrm{T}$. $\mathrm{N}$ saat ini memiliki investasi berupa tanah. $\mathrm{N}$ mengatakan alasan penggunaan bonus uang tunai untuk membeli tanah karena harga tanah semakin tahun semakin naik termasuk tanah yang ada di kampung halaman. Sebelum pandemi Covid-19, N mengatakan berencana membangun kontrakan di atas tanah yang dibelinya.

Dari data di atas diketahui bahwa instrumen investasi yang dipilih atlet yaitu tanah dan properti berupa kontrakan. Pilihan instrumen tersebut menunjukkan bahwa $\mathrm{T}$ dan $\mathrm{N}$ termasuk investor konvensional yang memilih instrumen stabil dan aman namun tetap memberikan nilai tambah di kemudian hari. Tanah dan properti juga dipilih dengan tujuan meminimalisir risiko yang mungkin timbul.

Atlet memiliki karier yang relatif singkat dibandingkan profesi lain. Perencanaan pensiun dan tempat tinggal ditanyakan kepada empat informan. Didapatkan informasi mengenai rencana saat pensiun dari olahraga dan tempat tinggal. T mengatakan sudah memiliki rencana untuk menjadi pelatih angkat besi setelah pensiun dari olahraga. $T$ sudah memiliki rumah yang dibangunnya dan ditempati istri serta dua anaknya. $\mathrm{N}$ mengatakan berencana untuk membuka usaha kuliner sebagai persiapan saat 
pensiun dari olahraga. Untuk rencana tempat tinggal, $\mathrm{N}$ mengatakan rumah yang ditempati bersama keluarga saat ini memiliki sertifikat atas nama $\mathrm{N}$ termasuk tanah yang dibelinya untuk investasi. $\mathrm{S}$ mengatakan sudah memiliki rencana menjadi atlet tinju karena melihat potensi diri sebagai pelatih. Sedangkan atlet tinju A mengatakan belum memiliki rencana saat pensiun dari olahraga. A saat ini termasuk sebagai pegawai negeri sipil Kemenpora. Untuk tempat tinggal, keduanya mengatakan sudah memiliki rumah atas nama sendiri.

Pada masa pandemi Covid-19, tabungan memainkan peranan penting untuk memenuhi kebutuhan atlet yang terkena dampak pandemi seperti atlet $\mathrm{N}$ dan $\mathrm{S}$. Hal tersebut sesuai dengan penelitian Martin, Markhvida, Hallegatte, S., \& Walsh, B. (2020) yang menyebutkan bahwa tanpa jaring pengaman sosial, pandemi Covid-19 yang menyebabkan guncangan ekonomi membuat tabungan yang dimiliki rumah tangga berkurang yang salah satunya disebabkan karena hilangnya pendapatan. Menurut Ghamdi (2016) Sumber daya keuangan juga menjadi salah satu faktor utama kinerja atlet di lapangan (Sumarno \& Irianto, 2019). Perencanaan keuangan keempat informan seperti menggunakan bonus uang tunai untuk investasi dan menabung serta memiliki rumah sesuai dengan Walny \& Shenkman (2012) yang menyebutkan bahwa apa yang dilakukan atlet tersebut merupakan cara untuk mengamankan hasil kerja keras untuk kestabilan masa depan agar kesalahan yang dilakukan atlet-atlet berprestasi dulu tidak dialami keempat informan.

\section{Peran Federasi dalam Perencanaan Keuangan Atlet}

Manajer angkat besi Alamsyah Wijaya mengetahui hal tersebut dan mengakui cukup banyak atlet yang sudah pensiun dari olahraga mengalami kesulitan keuangan. Alamsyah Wijaya mengatakan bahwa federasi tidak memiliki cukup anggaran untuk membantu pensiunan atlet tersebut. Perencanaan keuangan yang pernah disiapkan federasi untuk membantu atlet berprestasi yang akan pensiun dari olahraga salah satunya yaitu memberikan pekerjaan. Alamsyah Wijaya mengatakan sebelum tahun 2000, banyak atlet angkat besi yang diangkat menjadi pegawai Badan Usaha Milik Negara (BUMN) seperti kantor Pos dan Telkom. Hal tersebut bisa terjadi karena ketua umum PB PABBSI saat itu Susilo Sudharma juga merupakan Menteri Pariwisata, Pos dan Telekomunikasi (Kabinet Pembangunan V 1988-1993).

\section{Perencanaan Pendidikan \\ Pendidikan bagi Atlet Indonesia}

Keempat informan dalam penelitian ini memiliki pendidikan terakhir SMA dan belum memiliki rencana melanjutkan kuliah. Atlet angkat besi T merupakan lulusan SMA. T mengatakan banyak atlet yang menomorduakan belajar setelah latihan. T menuturkan bahwa pendidikan bisa dilanjutkan setelah atlet pensiun karena kalau dipaksakan sekolah sambil mempertahankan prestasi olahraga akan sulit karena tuntutan kuliah yang harus masuk setiap hari. Mempertahankan prestasi juga bentuk tanggung jawab atlet karena sudah dibiayai oleh pemerintah. T mengungkapkan pernah ditawari kuliah oleh Universitas di Jakarta tetapi tidak diambil. Tidak hanya kuliah, T juga tidak mengikuti kursus untuk mengembangkan soft skill. Rencana $\mathrm{T}$ setelah berhasil mutasi ke kampung istrinya. Kuliah bagi $\mathrm{T}$ didasari kebutuhan menaikkan golongan pegawai negeri sipil.

Atlet angkat berat $\mathrm{N}$ mengungkapkan setelah lulus SMA mau melanjutkan kuliah namun saat itu di akhir pendaftaran $\mathrm{N}$ mengikuti kejuaraan di luar daerah. $\mathrm{N}$ mengatakan ada penyesalan karena tidak melanjutkan kuliah hingga hari ini. Mengenai rencana melanjutkan kuliah, $\mathrm{N}$ mengungkapkan akan melanjutkan kuliah saat butuh tetapi masih fokus meniti karier atlet. Atlet tinju A dan S mengatakan setelah lulus SMA tidak melanjutkan kuliah karena fokus di olahraga. Baru saat diangkat menjadi pegawai negeri sipil S mengungkapkan perlu melanjutkan kuliah untuk meningkatkan penghasilan.

Sebagian besar atlet berprestasi memilih fokus mempertahankan karier sebagai atlet tanpa memilih melanjutkan pendidikan tinggi. Hal tersebut bisa dilihat dari data kepegawaian Kementerian Pemuda dan Olahraga yang menunjukkan dari 286 atlet berprestasi yang diangkat menjadi Calon Pegawai Negeri Sipil (CPNS) terhitung mulai tanggal 1 bulan Maret tahun 2019, hanya 72 atlet yang berijazah pendidikan tinggi dengan rincian 4 atlet merupakan lulusan diploma (D3) dan 68 atlet merupakan sarjana (S1). Sedangkan sebanyak 214 atlet atau 75\% atlet berprestasi yang diangkat CPNS tahun 2019 berpendidikan terakhir SMA dan sederajat.

Dari data di atas diketahui alasan atlet lebih memilih fokus mempertahankan karier dan tidak melanjutkan pendidikan tinggi diantaranya karena fokus berlatih sebagai atlet. Hal tersebut sesuai 
dengan penelitian Subijana, Barriopedro \& Conde (2019) yang menyebutkan bahwa rendahnya akademik atlet disebabkan karena atlet sedang berada di masa puncak performa dengan beban Latihan yang tinggi dan kehilangan minat akademik. Tingkat pendidikan sangat berpengaruh pada golongan CPNS atlet yang juga berimbas pada gaji pokok, tunjangan serta uang makan yang diterima atlet. Dari data di atas 68 atlet memiliki golongan III/a, II/c sebanyak 4 orang dan 214 atlet memiliki pangkat II/a. Rincian gaji pokok berdasarkan Peraturan Presiden Nomor 16 tahun 2019, tunjangan kinerja dan uang makan berdasarkan Peraturan Menteri Keuangan Nomor 78/PMK.02/2019 bisa dilihat pada tabel di bawah ini:

Tabel 1. Rincian gaji pokok dengan Masa Kerja Golongan terendah, tunjangan kinerja dan uang makan CPNS Atlet Berprestasi

\begin{tabular}{cccc}
\hline Gol & Gaji Pokok & $\begin{array}{c}\text { Tunjangan } \\
\text { Kinerja }\end{array}$ & $\begin{array}{c}\text { Uang makan per hari } \\
\text { kerja }\end{array}$ \\
\hline II/a & Rp. 2.022 .200 & Rp. 1.919 .200 & Rp. 35.000 \\
\hline II/c & Rp. 2.301 .800 & Rp. 1.919 .200 & Rp.35.000 \\
\hline III/a & Rp.2.579.400 & Rp.2.092.800 & Rp.41.000 \\
\hline
\end{tabular}

\section{Peran Organisasi dalam Pendidikan Atlet Indonesia}

PB PABBSI melalui Kepala Bidang Pembinaan dan Prestasi (Kabid Binpres) Alamsyah Wijaya yang juga tim manajer angkat besi di beberapa kejuaraan internasional mengungkapkan bahwa federasi ikut andil dalam mempersiapkan pensiun atlet dengan memfasilitasi atlet-atlet pelatnas melanjutkan pendidikan tinggi. Kesempatan yang diberikan federasi secara gratis sebagai hasil kerja sama dengan lembaga pendidikan tinggi tidak dimanfaatkan oleh atlet karena saat ditawari untuk kuliah atlet tidak mau karena mereka berpikir waktu yang ada di pelatnas habis untuk training dan recovery serta waktu luang dipakai bersama keluarga jika atlet tersebut sudah berkeluarga. Tidak hanya gratis, atlet juga diberikan keringanan dalam menjalankan pendidikan tinggi.

Hal tersebut dikonfirmasi atlet angkat besi $\mathrm{T}$ yang mengatakan pernah ditawari beasiswa dari Universitas di Jakarta namun tidak diambil. Waktu menjadi persoalan utama bagi atlet dalam memutuskan melanjutkan pendidikan tinggi. Selain pendidikan formal, ada dari atlet-atlet berprestasi yang tidak memungkinkan mendapatkan pendidikan formal baik karena faktor usia maupun faktor lainnya. Asisten Deputi Tenaga dan Peningkatan Sumber Daya Pemuda Kemenpora Dr. Deswan, M.Si mengatakan Kemenpora sedang menyusun kebijakan agar atlet-atlet berprestasi yang termasuk dalam kategori ini bisa tetap mendapatkan peningkatan pendapatan melalui jabatan fungsional sehingga atlet bisa mendapatkan penilaian kredit dari latihan atau jika atlet tersebut menjadi pelatih bisa mendapatkan penilaian kredit dari jam melatih dan karya-karya ilmiah terkait pembinaan atlet. Selain itu Dr. Deswan, M.Si yang juga mantan atlet pencak silat mengatakan Kemenpora saat ini sedang menyusun kebijakan untuk membangun tiga karakter utama yang harus dimiliki atlet-atlet berprestasi. Tiga karakter utama tersebut yaitu Kepercayaan Diri dan Motivasi, Kepemimpinan Pribadi dan Kemandirian.

\section{Penilaian Atlet terhadap Apresiasi Pemerintah}

Apresiasi yang sudah diberikan pemerintah baik melalui bonus uang tunai dan pengangkatan CPNS mendapat respons positif dari atlet dan manajer tim. Nada positif disampaikan oleh atlet angkat besi T serta atlet yang diangkat menjadi CPNS Kemenpora yang diangkat pada tahun 2019, N, S dan A. $\mathrm{N}$ mengungkapkan dengan diangkat menjadi CPNS, dirinya memiliki masa depan yang jelas dan dihargai. Atlet tinju A dan S menyatakan bahwa pengangkatan CPNS yang dilakukan pemerintah sudah tepat karena sudah memperhatikan atlet berprestasi dengan baik. S menambahkan dirinya bangga bisa menjadi CPNS.

\section{KESIMPULAN}

Berdasarkan hasil wawancara kepada empat informan yang merupakan atlet berprestasi dan pegawai negeri sipil serta hasil wawancara dengan satu perwakilan federasi dalam penelitian ini ditambah pembahasan dari pernyataan yang disampaikan informan, didapatkan kesimpulan bahwa :

1. Terdapat dua perencanaan yang menjadi bagian dalam manajemen risiko yang tidak hanya dilakukan oleh individu yaitu atlet tetapi juga dilakukan pada tingkatan organisasi. Kedua perencanaan dalam manajemen risiko tersebut yaitu perencanaan keuangan dan perencanaan 
pendidikan. Keempat informan yang merupakan atlet berprestasi dan pegawai negeri sipil Kemenpora hanya memiliki perencanaan keuangan dan tidak memiliki perencanaan pendidikan untuk melanjutkan pendidikan tinggi dan tidak mengambil kursus apapun. Perencanaan keuangan yang dimiliki atlet dalam penelitian ini yaitu tabungan, investasi berupa tanah, sawah dan kontrakan, perencanaan pensiun dan tempat tinggal. Pada tingkat organisasi, federasi menyiapkan atlet memasuki masa pensiun melalui perencanaan pendidikan yaitu menghubungkan atlet dengan beasiswa yang dimiliki universitas.

2. Manajemen risiko yang dimiliki atlet masih membuat atlet rentan terpapar risiko saat pensiun dari olahraga. Perencanaan keuangan yang dimiliki atlet seperti investasi, tabungan dan tempat tinggal bisa habis karena atlet tidak memiliki perencanaan yang bisa melindungi aset dan penghasilan yang dimiliki seperti asuransi dan pendidikan. Asuransi sangat dibutuhkan atlet ketika mengalami cedera dan harus beristirahat dalam waktu yang lama untuk menutupi biaya pengobatan. Tanpa asuransi, atlet akan menggunakan penghasilan, tabungan hingga aset untuk menutup biaya pengobatan. Atlet juga membutuhkan pendidikan untuk meningkatkan penghasilan dan membuka sumber daya penghasilan baru. Tanpa pendidikan, atlet tidak menyadari menutup potensi penghasilan yang mungkin didapat jika memiliki pendidikan tinggi seperti golongan pegawai negeri sipil. Dengan pendidikan, atlet juga bisa meniti karir profesional di luar karir di dunia olahraga sehingga atlet bisa tetap mendapatkan penghasilan saat pensiun dari karirnya.

\section{Rekomendasi}

Berdasarkan hasil penelitian dan kesimpulan, beberapa rekomendasi dapat diberikan penulis dengan membagi dua rekomendasi menjadi rekomendasi untuk perencanaan pendidikan dan rekomendasi untuk perencanaan keuangan. Rendahnya minat dan motivasi atlet berprestasi Indonesia terhadap pendidikan tinggi sudah diketahui Kemenpora. Hal tersebut diungkapkan oleh Asisten Deputi Tenaga dan Peningkatan Sumber Daya Pemuda Dr. Deswan, M.Si yang juga merupakan mantan atlet pencak silat. Sehingga hal tersebut menjadi permasalahan yang memiliki urgensi untuk diselesaikan. Beberapa rekomendasi terkait perencanaan pendidikan atlet yang bisa diberikan antara lain :

1. Pemerintah perlu memastikan atlet menyadari pentingnya pendidikan dengan membuka kesempatan seluas-luasnya kepada atlet dengan kebijakan berupa beasiswa afirmasi atau membuat regulasi agar federasi memastikan atlet-atlet yang dibinanya memiliki pendidikan tinggi minimal sarjana. Beasiswa afirmasi seperti beasiswa santri LPDP penting dibuat agar beasiswa bagi atlet tidak timbul tenggelam.

2. Bagi atlet yang tidak memungkinkan mendapatkan pendidikan formal, pemerintah dan federasi bisa membuat program-program keterampilan dan atau pengembangan diri bagi atlet di luar program pelatih, seperti kursus bahasa inggris, public speaking dan perencanaan keuangan agar keterampilan atau program pengembangan diri tersebut bisa melengkapi pengetahuan yang sudah dimiliki atlet.

Rekomendasi terkait perencanaan keuangan bisa dibagi menjadi dua bagian yaitu pada tingkat individu maupun pada tingkat organisasi, beberapa rekomendasi tersebut seperti:

1. Pada tingkat individu, Kemenpora selaku pemberi bantuan bisa melakukan monitoring terhadap atlet yang sudah menerima honorarium atau bonus uang tunai agar Kemenpora memiliki data mengenai manfaat dan kegunaan dana yang sudah diterima atlet. Kemenpora juga bisa bekerjasama dengan Bappenas atau BPS untuk melakukan survey ekonomi atlet sehingga Kemenpora memiliki dasar untuk mengevaluasi kebijakan yang sudah ada ataupun menjadi dasar untuk membuat kebijakan baru bagi atlet berprestasi.

2. Pada tingkat organisasi, Kemenpora bisa mendorong BUMN-BUMN untuk menjadi bapak asuh federasi-federasi yang berpotensi meraih prestasi di tingkat internasional. Tugas bapak asuh yaitu memastikan keberlangsungan pembinaan atlet bisa menggunakan dana CSR serta mengangkat atlet-atllet berprestasi menjadi pegawai di BUMN tersebut. Kebijakan pengangkatan pegawai negeri sipil tidak akan bertahan lama karena keterbatasan kuota dan akan semakin membenahi keuangan negara. 


\section{REFERENSI}

Aasa, U., Svartholm, I., Andersson, F., \& Berglund, L. (2017). Injuries among weightlifters and powerlifters: a systematic review. British journal of sports medicine, 51(4), 211-219.

Bledsoe, G. H., Li, G., \& Levy, F. (2005). Injury risk in professional boxing. Southern medical journal, 98(10), 994-999.

Balliauw, M., \& Van Den Spiegel, T. (2018). Managing professional footballers' finances to avoid financial problems. Sport, Business and Management: An International Journal.

Carlson, K., Kim, J., Lusardi, A., \& Camerer, C. F. (2015). Bankruptcy rates among NFL players with short-lived income spikes. American Economic Review, 105(5), 381-384.

Danowski, C. (2012). The importance of financial management for professional athletes and the prevention of bankruptcy.

Fox, G., West, J., \& Drew, M. (2012). Wealth portfolios and elite professional athletes. Journal of Financial Services Marketing, 17(4), 273-283.

Kapoor, J. R., Dlabay, L. R., \& Hughes, R. J. (2009). Personal finance: McGraw-Hill Irwin Boston, MA.

Lomboy, C. G., Belinario, F., Pomeroy, R., Pedrajas, J., Tirona, R. S., Box, S., Balbido-Ramirez, K. (2019). Building household economic resilience to secure a future for near shore fishers in the Philippines. Marine Policy, 99, 334-342.

Martin, A., Markhvida, M., Hallegatte, S., \& Walsh, B. (2020). Socio-Economic Impacts of COVID19 on Household Consumption and Poverty. Economics of Disasters and Climate Change, 1-27.

Nasution, D. A. D., Erlina, E., \& Muda, I. (2020). Dampak Pandemi COVID-19 terhadap Perekonomian Indonesia. Jurnal Benefita: Ekonomi Pembangunan, Manajemen Bisnis \& Akuntansi, 5(2), 212-224.

Stambulova, N., Stephan, Y., \& Jäphag, U. (2007). Athletic retirement: A cross-national comparison of elite French and Swedish athletes. Psychology of Sport and exercise, 8(1), 101-118.

Subijana, C. L., Barriopedro, M., \& Conde, E. (2015). Supporting dual career in Spain: Elite athletes' barriers to study. Psychology of Sport and Exercise, 21, 57-64.

Sumarno, S., \& Irianto, D. P. (2019). Studi eksplorasi klub sepakbola pada Liga 2 Indonesia 2018: Bagaimana cara bertahan dalam keterbatasan?. Jurnal Keolahragaan, 7(2), 104-115.

Toresdahl, B. G., \& Asif, I. M. (2020). Coronavirus Disease 2019 (COVID-19): Considerations for the Competitive Athlete. Sports Health, 12(3), 221-224. https://doi.org/10.1177/1941738120918876.

Walny, E. M., \& Shenkman, M. M. (2012). Pro athlete clients: Spring training for estate planners. Estate Planning (Tampa), 39(3), 14.

Peraturan Menteri Keuangan Nomor 78/PMK.02/2019 tentang Standar Biaya Masukan Tahun Anggaran 2020.

Peraturan Presiden Nomor 16 Tahun 2019 tentang Penyesuaian Gaji Pokok Pegawai Negeri Sipil Menurut Peraturan Pemerintah Nomor 30 Tahun 2015 ke Dalam Gaji Pokok Pegawai Negeri Sipil Menurut Peraturan Pemerintah Nomor 15 Tahun 2019.

Undang-undang No 3 Tahun 2005 tentang Sistem Keolahragaan Nasional.

Kemenpora. (2018a). Menpora Pastikan Peralatan, Nutrisi, hingga Uang Saku Atlet Asian Para Games 2018 Selama Pelatnas Tidak Masalah. Retrieved from http://www.kemenpora.go.id/index/preview/berita/12839

Kurnia, T. (2019). Nasib Atlet Usai Pensiun, Terpaksa Jual Medali hingga Jadi Tukang Sapu. Retrieved from https://www.liputan6.com/bisnis/read/4019536/nasib-atlet-usai-pensiunterpaksa-jual-medali-hingga-jadi-tukang-sapu

Saputra, R. (2016). Mazda Biante Banting Harga. Retrieved from https://www.viva.co.id/otomotif/mobil/760738-mazda-biante-banting-harga. 
Setkab.go.id. (2018). Selain Jadi CPNS, Pemerintah Siapkan Bonus Besar dan Rumah Bagi Peraih Medali Asian Games 2018. Retrieved from https://setkab.go.id/selain-jadi-cpns-pemerintahsiapkan-bonus-besar-dan-rumah-bagi-peraih-medali-asian-games-2018/ . (2016). Paket Kredit Mobil Mazda Murah Banjarmasin 2016. 